\title{
End User Functional and Performance Requirements for HTGR Energy Supply to Industrial Processes
}

The INL is a

U.S. Department of Energy National Laboratory

operated by

Battelle Energy Alliance

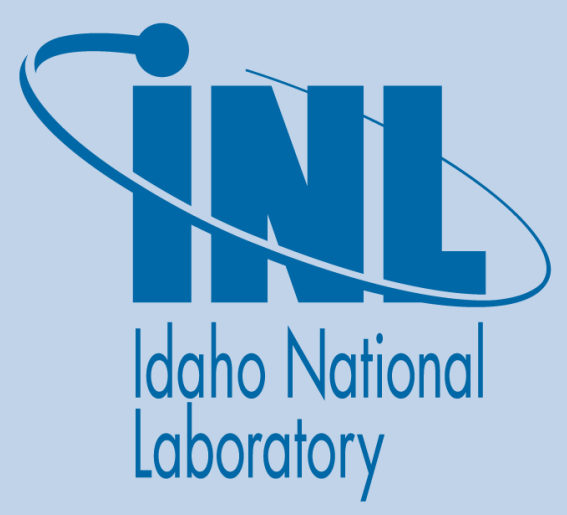

September 2010

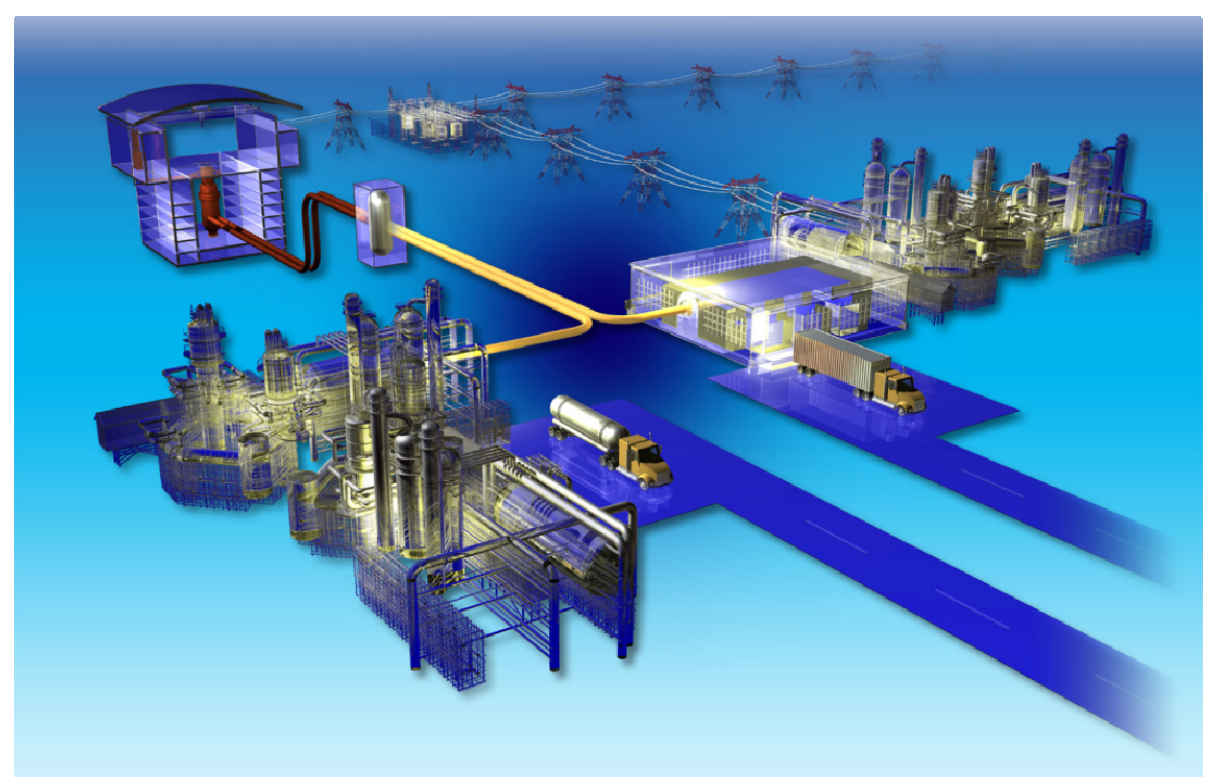




\section{DISCLAIMER}

This information was prepared as an account of work sponsored by an agency of the U.S. Government. Neither the U.S. Government nor any agency thereof, nor any of their employees, makes any warranty, expressed or implied, or assumes any legal liability or responsibility for the accuracy, completeness, or usefulness, of any information, apparatus, product, or process disclosed, or represents that its use would not infringe privately owned rights. References herein to any specific commercial product, process, or service by trade name, trade mark, manufacturer, or otherwise, does not necessarily constitute or imply its endorsement, recommendation, or favoring by the U.S. Government or any agency thereof. The views and opinions of authors expressed herein do not necessarily state or reflect those of the U.S. Government or any agency thereof. 


\section{End User Functional and Performance Requirements for HTGR Energy Supply to Industrial Processes}

September 2010

Idaho National Laboratory

Next Generation Nuclear Plant Project

Idaho Falls, Idaho 83415

Prepared for the

U.S. Department of Energy

Office of Nuclear Energy

Under DOE Idaho Operations Office

Contract DE-AC07-05ID14517 



\title{
Next Generation Nuclear Plant Project
}

\section{End User Functional and Performance Requirements for HTGR Energy Supply to Industrial Processes}

\author{
INL/EXT-10-19808
}

September 2010

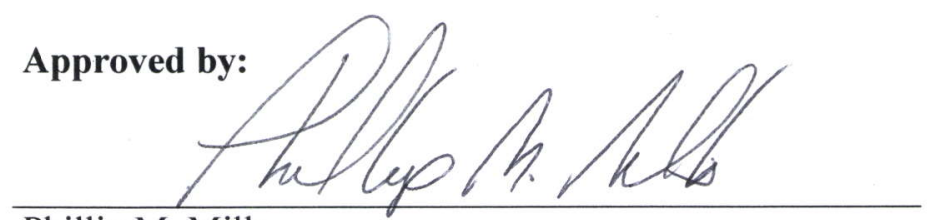

Phillip M. Mills

NGNP Engineering Director (acting)

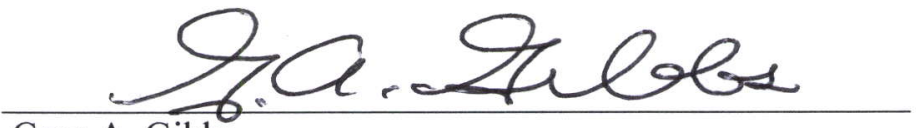

Greg A. Gibbs

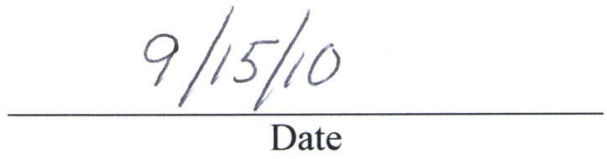

NGNP Project Director

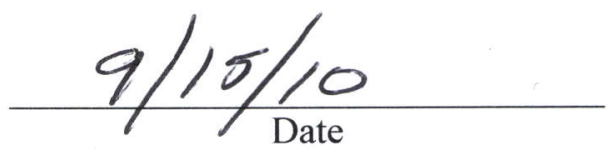





\begin{abstract}
This document specifies end user functional and performance requirements to be used in the development of the design of a high temperature gas-cooled reactor (HTGR) based plant supplying energy to industrial processes. These requirements were developed from collaboration with industry and HTGR suppliers and from detailed evaluation of integration of the HTGR technology in industrial processes. The functional and performance requirements specified herein are an effective representation of the industrial sector energy needs and an effective basis for developing a plant design that will serve the broadest range of industrial applications.
\end{abstract}




\section{CONTENTS}

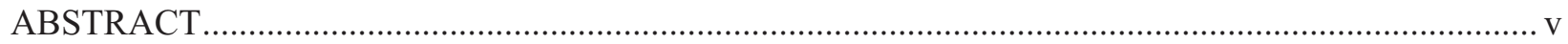

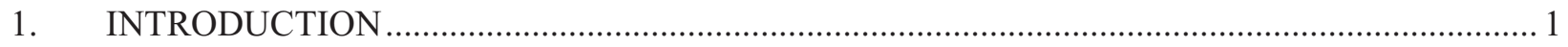

2. OBJECTIVE

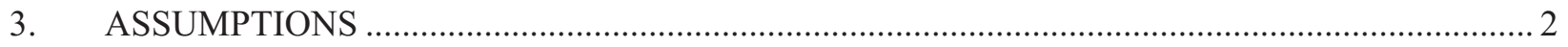

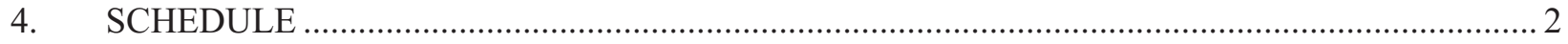

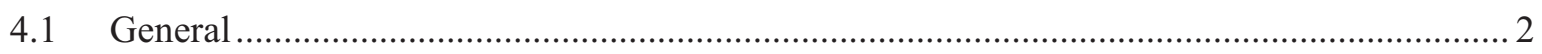

4.2 Plant Deployment Schedule and Information Requirements .............................................. 2

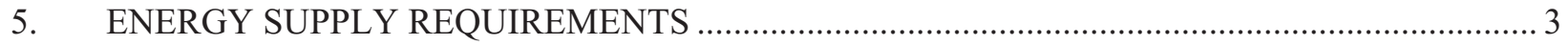

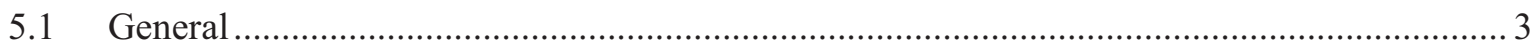

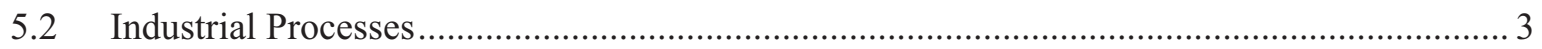

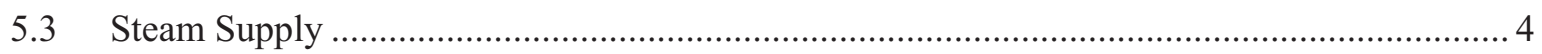

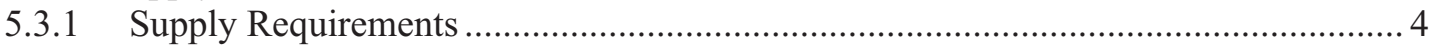

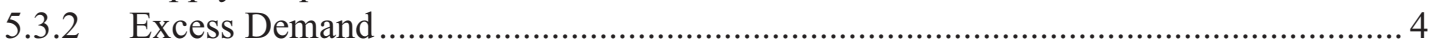

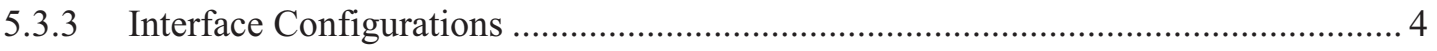

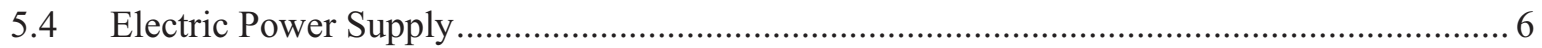

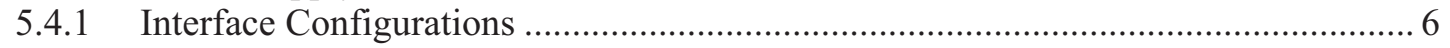

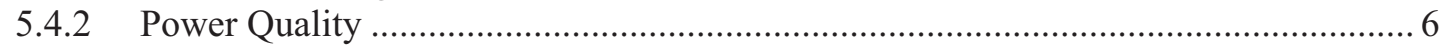

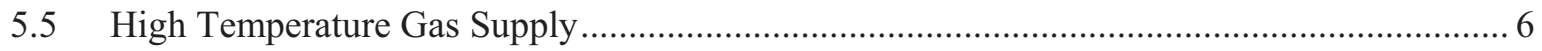

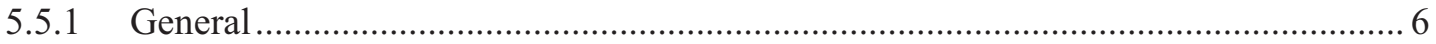

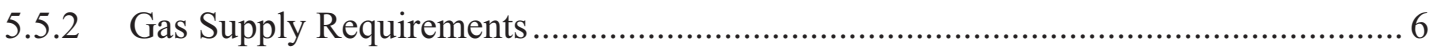

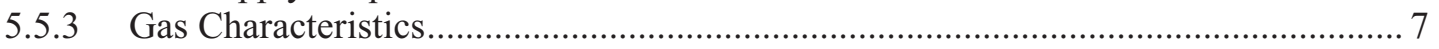

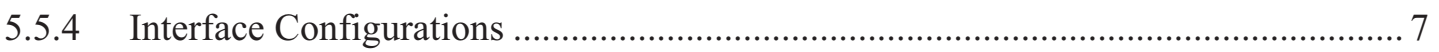

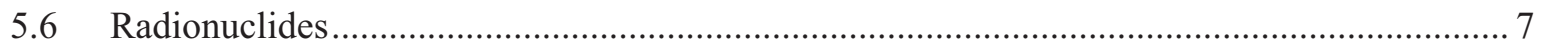

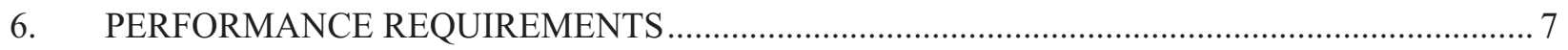

6.1 Normal and Emergency Demand Transients ............................................................. 7

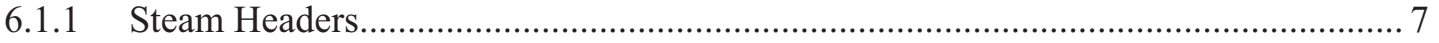

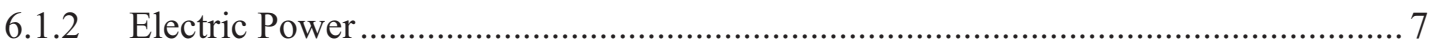

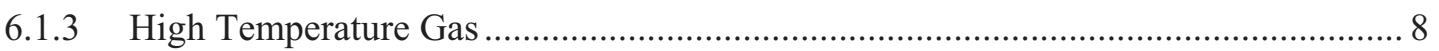

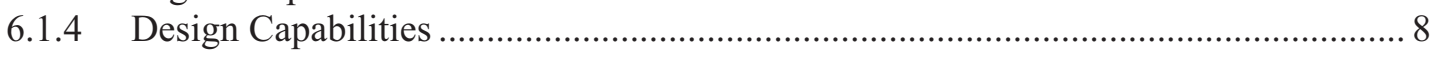

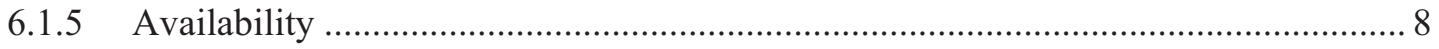

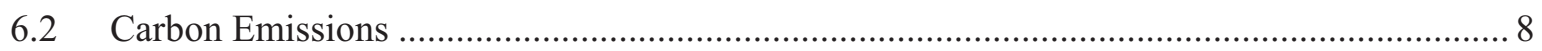

Appendix A—Results of End User Requirements Evaluations ........................................................ 9

\section{FIGURES}

Figure 1. Functional and performance requirements development flow path........................................ 1

Figure A-1. Power conversion efficiency versus ROT. ..................................................................... 12

Figure A-2. Ammonia and ammonia derivatives production................................................................... 14 
Figure A-3. Coal to Gasoline Conversion using the MTG Process. ................................................... 15

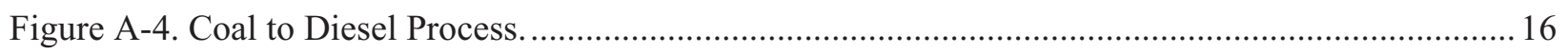

Figure A-5. Use of the HTGR as an energy source in the Steam Methane Reforming Process................ 17

Figure A-6. HTGR Integrated Steam Methane Reforming Process Performance versus ROT................. 18

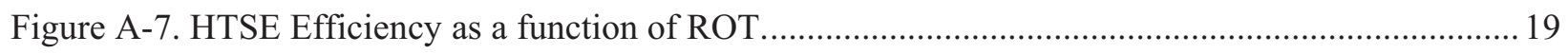

\section{TABLES}

Table 1. Summary of ranges for energy supply characteristics. ....................................................... 4

Table A-1. Summary of evaluated power conversion system technologies. ............................................ 12

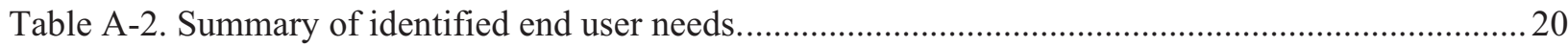




\section{End User Functional and Performance Requirements for HTGR Energy Supply to Industrial Processes}

\section{INTRODUCTION}

This document provides end user functional and performance requirements for application of the high temperature gas-cooled reactor (HTGR) technology for supply of energy to industrial processes. These requirements envelop the broad range of energy needs identified by the NGNP Project in collaboration with industrial potential end users and in assessments of the technical and economic viability of integrating the HTGR technology in industrial processes. These requirements apply to the nuclear heat supply system and the energy conversion system; the latter may comprise either or both a heat transport system and power conversion system. As shown in Figure 1, the requirements for the energy conversion system derive from the end user process requirements and at the interfaces inform the nuclear heat supply system requirements. In Figure 1 a hydrogen production system is shown in addition to a generic process requirements block. Although the hydrogen production system is a specific industrial process that places demands on the energy conversion system and ultimately the nuclear heat supply system, it is addressed separately herein to include the requirements that derive from the NGNP Project hydrogen production system development task.

A typical HTGR plant can be comprised of multiple identical reactor modules or multiple reactor modules of differing ratings and configurations that fulfill the requirements herein. These end user functional and performance requirements shall be used to establish the requirements and design characteristics of the Energy Conversion System and the Nuclear Heat Supply system.

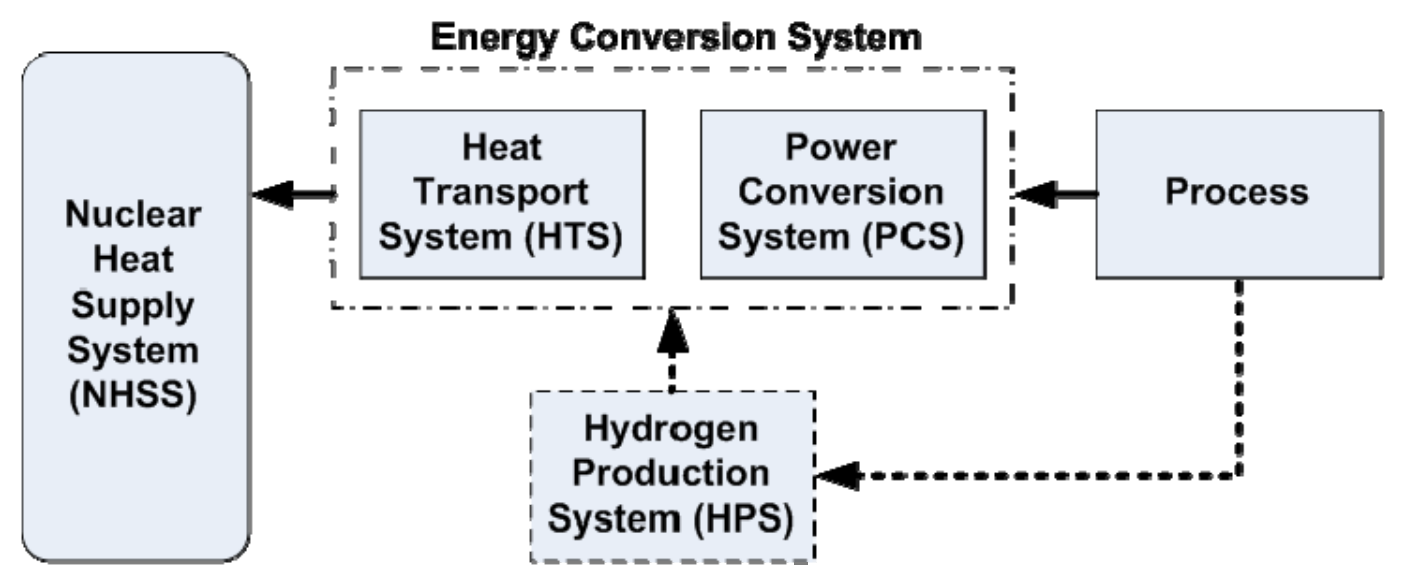

Figure 1. Functional and performance requirements development flow path.

These requirements represent a composite of information from discussions and detailed evaluations of energy needs jointly performed by INL and potential industrial end users. Appendix A summarizes the results of the evaluations performed to the time of this writing. These requirements will be updated as warranted as additional data is obtained.

For purposes of this document, the following definitions apply:

End User The entity whose Facility is being supplied the required energy in the forms specified and on whose property the HTGR energy supply is located 
Purchaser The entity who purchases the energy from the Supplier, anticipated to occur via a long term energy purchase agreement

Supplier The entity who owns the HTGR energy supply

Operator The entity that is licensed to operate the HTGR energy supply

Designer The entity that performs the design of the HTGR energy supply and supports the licensing activities by the Operator

\section{OBJECTIVE}

The objective of this document is to define end user requirements for an HTGR based energy supply system that meets the full range of energy needs of industrial processes evaluated to-date by the NGNP Project.

\section{ASSUMPTIONS}

1. This specification does not include commercial issues.

2. The Purchaser of energy will enter into a contract with the Supplier for long term supply of energy.

3. The HTGR plant (hereinafter referred to as the "Plant") will be operated by an entity other than the Purchaser

4. The Purchaser will support the Supplier in providing and developing data and information required to obtain a combined license for construction and operation of the HTGR energy source

5. The HTGR Plant will be sited within or adjacent to the Facility controlled area. The selected site for the Plant will depend on site surveys conducted to support licensing of the Plant by the USNRC. The HTGR energy supply plant site will be a separate facility within or adjacent to the Facility controlled area but will be under the control of the Plant Operator as required by the USNRC for an operating nuclear plant.

\section{SCHEDULE}

\subsection{General}

The HTGR Energy supply shall be fully operational no later than January 1, 20xx. The Supplier shall provide a schedule for a phased deployment, including the increments of energy supplied in each phase and the accumulated capacity, in accordance with the requirements below, assuming a Greenfield application.

\subsection{Plant Deployment Schedule and Information Requirements}

The Supplier shall provide a detailed schedule for deployment of the HTGR energy supply. This schedule shall include as a minimum the following:

1. Development of the licensing strategy including requirements and timing for developing and submitting licensing documentation and applications

2. Plant Design 
3. Plant Licensing Reviews

4. For each increment of energy supply:
a. Procurement
b. Site mobilization
c. Construction
d. Cold and Hot Testing
e. Initial Operation
f. Full Operation

The schedule shall be provided in [Primavera format, Version 6 or later at level 3].

\section{ENERGY SUPPLY REQUIREMENTS}

\subsection{General}

The HTGR plant design shall have the capability to supply energy to the industrial process in the following forms:

- Steam for general use throughout the facility

- Electricity to support facility operation and

- Process heat in the form of high temperature gas to selected plant processes to offset the emissions of greenhouse gases attendant to the burning of natural gas and waste gases in these processes

Since this plant is intended to be the primary source of energy to the facility, $100 \%$ availability is required.

The electrical distribution system within the facility shall include a cross-connection with the regional electrical grid in addition to the facility distribution system to permit flow of electricity to or from the regional grid.

Not all applications will require supply of all of these forms of energy; however, the fundamental plant design shall be capable of providing any mix of these forms as required by each specific application.

\subsection{Industrial Processes}

At the time of this writing the NGNP Project has collaborated with industrial end users and performed several assessments of the technical and economic viability of integrating the HTGR technology with the industrial processes supplying the following:

- Steam, electricity and high temperature fluid (e.g., He, He-N, Air) for general facility use

- Steam for oil sands bitumen recovery. Supply of electricity to support facility operations and supply of hydrogen for upgrading the bitumen have also been identified as potential applications of the HTGR technology.

- Electricity using several different power conversion systems

- Hydrogen via high temperature steam electrolysis and steam methane reforming

- Ammonia and ammonia derivatives, (e.g., urea, ammonium nitrate, fertilizer)

- Coal and natural gas conversion to diesel fuel 
- Coal and natural gas conversion to gasoline

Appendix A summarizes the results from evaluations of applying the HTGR technology in each of these industrial processes. Table 1 summarizes the range of energy supply characteristics identified in these evaluations

Table 1. Summary of ranges for energy supply characteristics.

\begin{tabular}{|c|c|l|l|l|}
\hline $\begin{array}{c}\text { Reactor } \\
\text { Outlet } \\
\text { Temperature }\end{array}$ & Plant Rating & \multicolumn{1}{c|}{$\begin{array}{c}\text { Supplied Steam } \\
\text { Conditions }\end{array}$} & \multicolumn{1}{c|}{$\begin{array}{c}\text { Electricity } \\
\text { Requirements }\end{array}$} & $\begin{array}{c}\text { High } \\
\text { Temperature } \\
\text { Fluid Conditions }\end{array}$ \\
\hline 750 to $950^{\circ} \mathrm{C}$ & 250 to $6,900 \mathrm{MWth}$ & $\begin{array}{l}>4,000 \text { psig for super- } \\
\text { critical applications, } \\
2,500 \text { psig for } \\
\text { subcritical applications } \\
540 \text { to } 630^{\circ} \mathrm{C}\end{array}$ & $\begin{array}{l}\text { Up to } 2,500 \mathrm{MWe} \\
\text { investigated to-date. } \\
\text { As a supply to the } \\
\text { electrical grid a wide } \\
\text { range is possible } \\
\text { depending on the } \\
\text { location. }\end{array}$ & $\begin{array}{l}700 \text { to } 925^{\circ} \mathrm{C} \\
54 \text { to } 762 \mathrm{MWth}\end{array}$ \\
\hline
\end{tabular}

\subsection{Steam Supply}

\subsubsection{Supply Requirements}

The HTGR plant shall be designed to supply steam to steam turbine generators and the header system of the facility. The HTGR steam supply shall interface with steam turbine generators within the HTGR plant and/or with steam headers at the HTGR plant boundary. The steam pressures and temperatures at those interfaces shall account for pressure and temperature drops along the header system to ensure that the pressures and temperatures at the end use meet requirements.

Based on work completed to the time of this writing steam pressure and temperature requirements can range from the supercritical, (e.g., to supply supercritical steam turbine generators) to very low pressures, (e.g., 30 psig to $40 \mathrm{psig}$ at $50^{\circ} \mathrm{F}$ superheat).

The HTGR plant shall be designed to meet variations in steam demand from very low to maximum demand with demand characteristics as determined by the specific application and as specified in the sections below.

\subsubsection{Excess Demand}

Purchaser may exercise the option of increasing the steam demand for short periods of time. The notification and periods of increased demand shall be determined in the contract between the Supplier and the Purchaser.

\subsubsection{Interface Configurations}

The Designer shall coordinate with the Purchaser to define the specific configuration of the interfaces with the Facility steam headers. The following information shall be developed for each steam header as a minimum. 


\subsubsection{Steam Supply Headers}

\begin{tabular}{|c|c|c|c|c|c|}
\hline Header & $\begin{array}{c}\text { Pipe Diameter, } \\
\text { Inches }\end{array}$ & Schedule & Material & Insulation & Flange \\
\hline & & & & & \\
\hline & & & & & \\
\hline
\end{tabular}

\subsubsection{Over pressure protection}

Overpressure protection shall be provided by the Supplier at the steam source.

\subsubsection{Steam Chemistry}

Steam supplied to the steam headers shall meet the requirements of the ASME guideline "Consensus on Operating Practices for Control of Feedwater and Boiler Water Chemistry in Modern Industrial Boilers."a

\subsubsection{Condensate Return}

The Purchaser shall return condensate to the HTGR plant at a rate equal to the full steam demand plus makeup as required by the HTGR plant. ${ }^{\mathrm{b}}$ This condensate shall be returned in a single header. The Designer and Purchaser shall establish the following for this header as a minimum.

\begin{tabular}{|c|c|c|c|c|c|}
\hline Header & $\begin{array}{c}\text { Pipe Diameter, } \\
\text { Inches }\end{array}$ & Schedule & Material & Insulation & Flange \\
\hline & & & & & \\
\hline & & & & & \\
\hline
\end{tabular}

\subsubsection{Condensate Return and Makeup}

The Purchaser shall provide specifications for the makeup and condensate returned from the steam supplied to the headers including the following as a minimum:

- $\mathrm{pH}$

- Conductivity

- $\mathrm{TOC}$

- Oxygen

- Pressure

- Temperature

The Supplier shall provide any additional conditioning equipment required to meet the specification for feedwater or makeup water to the Plant.

a. Note that in some applications additional requirements for steam purity may also be mandated depending on the steam use (e.g. turbine driven compressors, etc.) in order to avoid unacceptable risk to component integrity or voiding of OEM warranties.

b. Makeup will be limited to the capacity of the Facility. Any required makeup in excess of the capacity of the Facility shall be provided by the Supplier. 


\subsubsection{Condensate and Steam Flow Metering}

The Supplier shall provide certified steam and condensate flow metering. Steam flow metering shall be pressure and temperature compensated.

\subsection{Electric Power Supply}

The HTGR plant shall be designed to supply electricity to the facility. The electrical supply shall be designed to be compatible with the facility electrical distribution system and the regional grid.

\subsubsection{Interface Configurations}

The Designer shall develop the configuration and design requirements for the electrical connection between the generator and low voltage taps on the facility distribution transformer and the regional grid transformer. The Supplier shall provide the transformers and power lines as required to connect with the facility distribution system and the regional grid.

\subsubsection{Power Quality}

The frequency and other properties and characteristics, (e.g., phase voltage imbalance) shall be as required by the regional electricity supply utility for operation on its electrical system. Power factor correction will be provided by the Supplier. For conceptual design work, Designer shall use typical requirements for the U.S. grid. These include as a minimum:

Distribution Voltage, KV (Facility)

(Regional Grid)

Phase

Frequency, hz (When islanded)

Power Factor

Facility Distribution Transformer, KVA

Regional Grid Transformer, KVA

\subsection{High Temperature Gas Supply}

\subsubsection{General}

The HTGR shall be designed to supply high temperature gas to selected processes in the facility according to the following:

- The high temperature gas supply circuit shall be isolated from the HTGR primary helium circuit.

- The working gas shall be compatible with the materials of construction in the gas circuit at all anticipated normal and abnormal operating conditions, (e.g., $\mathrm{He}, \mathrm{He}-\mathrm{N}_{2}$, Air)

- The working gas shall be compatible with standard circulator designs.

- A means to remove corrosion products and foreign objects shall be positioned in the gas circuit prior to entering the circulator

\subsubsection{Gas Supply Requirements}

Based on the work completed to the date of this writing gas supply pressures and temperatures have been identified as required from the HTGR plant. Following are the high temperature gas supply requirements. 
Gas Pressure at Header, psig

Supply Temperature at Header, ${ }^{\circ} \mathrm{C}$

Return Temperature at Header, ${ }^{\circ} \mathrm{C}$
1000

700 to $925^{\circ} \mathrm{C}$

325 to $520^{\circ} \mathrm{C}$

\subsubsection{Gas Characteristics}

The Designer shall provide suggested ranges for gas characteristics based on compatibility with HTGR energy supply design and materials of construction. The Designer and Purchaser shall determine the required gas chemistry conditions to satisfy both the HTGR plant and the process requirements to include as a minimum:

$\begin{array}{ll}\text { Oxygen } & \text { [upper and lower limits TBD }] \\ \text { Nitrogen } & <[\mathrm{TBD}] \mathrm{ppm} \\ \text { Moisture } & {[\text { upper and lower dew point TBD] }} \\ \text { Hydrogen } & <[\mathrm{TBD}] \mathrm{ppm} \\ \text { Carbon Dioxide } & <[\mathrm{TBD}] \mathrm{ppm}\end{array}$

\subsubsection{Interface Configurations}

The interface headers shall be specified as follows:

\begin{tabular}{|l|c|c|c|c|c|}
\hline \multicolumn{1}{|c|}{ Header } & $\begin{array}{c}\text { Pipe Diameter, } \\
\text { Inches }\end{array}$ & Schedule & Material & Insulation & Flange \\
\hline Supply & & & & & \\
\hline Return & & & & & \\
\hline
\end{tabular}

\subsection{Radionuclides}

Detectable levels of radionuclides in the steam and gas supplied to the processes by the HTGR that could be transported from the primary helium circuit or activated by exposure to the primary helium circuit shall be deminimus; defined as not exceeding levels detected in the steam and gases used in these processes supplied from non-HTGR sources.

\section{PERFORMANCE REQUIREMENTS}

\subsection{Normal and Emergency Demand Transients}

The HTGR Plant shall be capable of responding to the following process transients without interruption or degradation of supply:

\subsubsection{Steam Headers}

$\begin{array}{ll}\text { Step Change } & \pm 10 \% \\ \text { Maximum rate of change } & 20 \% / \text { min decreasing } \\ & 20 \% / \text { min increasing }\end{array}$

\subsubsection{Electric Power}

$$
\begin{array}{ll}
\text { Step Change } & \pm 10 \% \\
\text { Maximum rate of change } & 10 \mathrm{MW}_{\mathrm{e}} / \text { min decreasing } \\
& 10 \mathrm{MW}_{\mathrm{e}} / \text { min increasing }
\end{array}
$$




\subsubsection{High Temperature Gas}

$$
\begin{array}{ll}
\text { Step Change } & \pm 10 \% \\
\text { Maximum rate of change } & 20 \% / \text { min decreasing } \\
20 \% / \text { min increasing }
\end{array}
$$

\subsubsection{Design Capabilities}

1. Plant shall be capable of accepting a full load rejection from either steam, electrical or high temperature gas demand.

2. Plant shall be able to accept zero steam flow demand and/or zero power demand, and/or zero high temperature gas demand. If all demand is lost temporarily the HTGR plant shall remain capable of meeting demand as it is restored within a maximum time period to be supplied by the Designer.

6. Plant shall be capable of accommodating coincident average steam, electrical and high temperature gas demand.

7. Plant shall be capable of operating with zero condensate return from Purchaser for 2 full power days.

\subsubsection{Availability}

The average required supply of steam to the steam headers, high temperature gas to the gas headers and electrical power generation to the electrical interconnections shall be available $100 \%$ of the time ( 24 hours a day, 7 days a week, 365 (366 in leap years) days per year) with two of the nuclear heat supply modules out of service.

\subsection{Carbon Emissions}

The energy requirements summarized herein shall be achieved by the HTGR energy supply using solely nuclear heat. 
Appendix A

Results of End User Requirements Evaluations 


\section{Appendix A \\ Results of End User Requirements Evaluations}

The requirements summarized herein represent a composite of information from discussions and detailed evaluations of energy needs jointly performed by INL, the HTGR Suppliers and potential industrial end users. The following summarizes the results of the evaluations performed to the time of this writing. These will be updated as warranted as additional data is obtained.

\section{A-1. Steam Supply}

The steam supply needs include steam turbine generators (STG) and steam supply headers supplying industrial facilities in a co-generation application, (e.g., typically in conjunction with electricity and high temperature gas supplies [INL2009]), and wells heads supporting steam assisted gravity drainage (SAGD) bitumen recovery in oil sands [TEV-704]. These uses include a wide range of steam pressures, temperatures and demands as follows.

Rankine STG -

Supercritical STG

Process steam demands
2500 psig, $540^{\circ} \mathrm{C}$ to $593^{\circ} \mathrm{C}$ 3500 psig to $4500 \mathrm{psig}, 565^{\circ} \mathrm{C}$ to $630^{\circ} \mathrm{C}$

Several pressures from 2500 psig to 30 psig at temperatures ranging from saturation and up to several hundred ${ }^{\circ} \mathrm{C}$ superheat, typically extracted from sub critical stages of a steam turbine generator

The steam demands cover a very wide range depending on the facility.

Oil sands bitumen recovery $-2,500 \mathrm{psig}, 540^{\circ} \mathrm{C}$ at the HTGR; sufficient to produce secondary steam at $1500 \mathrm{psig}, 310^{\circ} \mathrm{C}$ for injection into the wells. A $600 \mathrm{MWt}$ HTGR based plant can support recovery of 56,000 barrels per day of bitumen

\section{A-2. Electricity Supply to the Grid}

Over a ROT range of $750^{\circ} \mathrm{C}$ to $950^{\circ} \mathrm{C}$ a potential net efficiency range of $40 \%$ to $48 \%$ has been estimated, see Figure A-1. The likely applications of an HTGR electrical supply to the grid would be in an area with minimum water supply and/or limited transmission and distribution capacity that could not support a larger plant.

Different power conversion technologies are needed to take advantage of the higher ROT to achieve these net efficiencies. At the lower temperatures $\left(<800^{\circ} \mathrm{C}\right.$ ROT $)$ the Rankine steam turbine generator cycle applies. Above $800^{\circ} \mathrm{C}$ direct Brayton, indirect Brayton combined cycle and supercritical $\mathrm{CO}_{2}$ technologies have been assessed.

The power conversion technologies investigated by the NGNP Project include those listed in Table A-1. [TEV-674, TEV-981] 


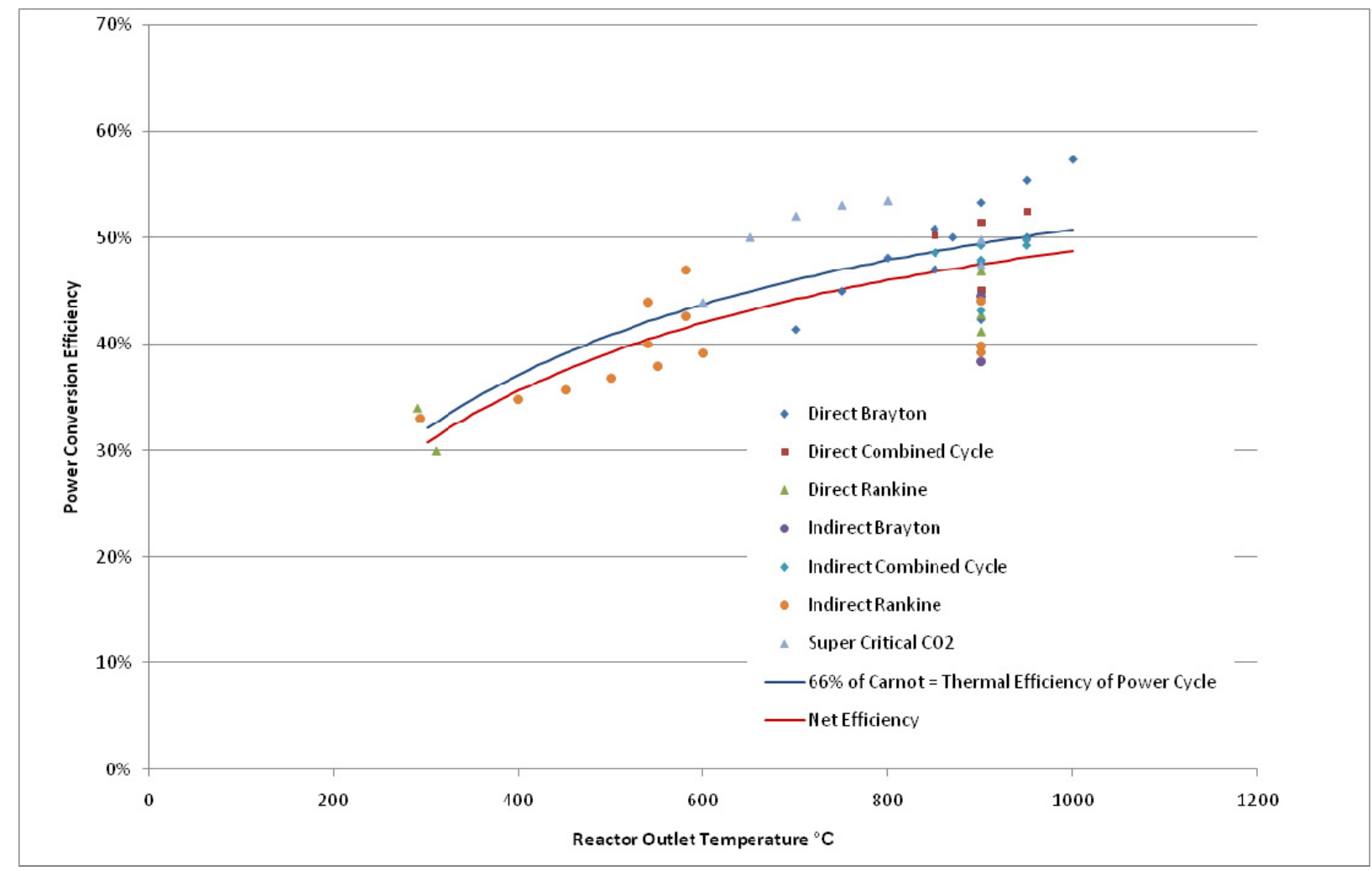

Figure A-1. Power conversion efficiency versus ROT.

Table A-1. Summary of evaluated power conversion system technologies.

\begin{tabular}{|l|l|l|l|l|}
\hline \multicolumn{1}{|c|}{ PCS Technology } & \multicolumn{1}{|c|}{ Fluid } & $\begin{array}{c}\text { Required } \\
\text { Supply Temp. }\end{array}$ & $\begin{array}{c}\text { Net } \\
\text { Efficiency }\end{array}$ & \multicolumn{1}{c|}{ Comment } \\
\hline $\begin{array}{l}\text { Rankine Steam } \\
\text { Turbine Generator }\end{array}$ & $\begin{array}{l}\text { Subcritical } \\
\text { steam }\end{array}$ & 540 to $590^{\circ} \mathrm{C}$ & 40 to $43 \%$ & $\begin{array}{l}\text { Current state-of-the-art applying typical coal } \\
\text { fired plant steam conditions. }\end{array}$ \\
\hline $\begin{array}{l}\text { Supercritical Steam } \\
\text { Turbine Generator }\end{array}$ & $\begin{array}{l}\text { Supercritical } \\
\text { steam }\end{array}$ & 565 to $630^{\circ} \mathrm{C}$ & 43 to $45 \%$ & $\begin{array}{l}\text { Provides higher net efficiencies. Advances have } \\
\text { been made in materials permitting the use of } \\
\text { these conditions. }\end{array}$ \\
\hline $\begin{array}{l}\text { Direct Brayton Gas } \\
\text { Turbine Generator }\end{array}$ & $\begin{array}{l}\text { Primary } \\
\text { circuit } \\
\text { helium }\end{array}$ & 850 to $950^{\circ} \mathrm{C}$ & 47 to $55 \%$ & $\begin{array}{l}\text { This technology is in development via a } \\
\text { collaboration between the US and Russia. }\end{array}$ \\
\hline $\begin{array}{l}\text { Indirect Brayton } \\
\text { Combined Cycle } \\
\text { Generator }\end{array}$ & $\begin{array}{l}\text { Secondary } \\
\text { circuit gas }\end{array}$ & 900 to $925^{\circ} \mathrm{C}$ & 38 to $45 \%$ & $\begin{array}{l}\text { The turbine section of this technology is highly } \\
\text { developmental. The subcritical section would } \\
\text { apply well known technology used in natural } \\
\text { gas fired combined cycle units. }\end{array}$ \\
\hline $\begin{array}{l}\text { Supercritical } \mathrm{CO}_{2} \\
\text { Generator }\end{array}$ & $\begin{array}{l}\text { Secondary } \\
\text { circuit } \mathrm{CO}_{2}\end{array}$ & 600 to $800^{\circ} \mathrm{C}$ & 44 to $53 \%$ & $\begin{array}{l}\text { Highly developmental including the need for a } \\
\text { helium to CO } \text { intermediate heat exchanger. } \\
\text { This could provide a significant efficiency } \\
\text { improvement and smaller PCS footprint. }\end{array}$ \\
\hline
\end{tabular}

a. The "Direct" notation refers to use of primary helium in the Brayton cycle.

b. The "Indirect" notation refers to a configuration that includes an intermediate heat exchanger between the primary helium circuit and a secondary gas circuit. The secondary gas circuit includes the Brayton cycle gas turbine. 


\section{A-3. Electricity supply to an industrial facility}

The power conversion technologies summarized in Table A-1 could be applied to supply electricity to an industrial facility. The selection of the technology should be coordinated with other energy needs. If a significant steam supply at medium to low pressure ranges is required, (e.g., for a typical petro-chemical plant) a supercritical or Rankine steam turbine generator with appropriate extractions may be preferred. If the electricity requirements dominate the energy requirements, (e.g., supplying a high temperature steam electrolysis hydrogen production facility) a higher temperature and higher net efficiency electrical generator may be favored with a smaller heat recovery or other steam generation facility. These selections will typically be driven by economics.

\section{A-4. High Temperature Fluids}

To the date of this writing helium, helium-nitrogen and air have been assessed for use in the secondary circuit for transport of high temperatures from the nuclear heat supply system through an intermediate heat exchanger to the process. Specific applications that require high temperature fluid include:

- Indirect Brayton combined cycle power conversion system as identified above.

- Supply to selected industrial plant processes as a substitute for burning natural gas and waste gases

The specific conditions required to support some of the industrial plant processes that have been evaluated for use of the HTGR energy source are proprietary to the end user. In general these have gas temperature requirements in the $800^{\circ} \mathrm{C}$ to $950^{\circ} \mathrm{C}$ range with ratings in the $200 \mathrm{MW}_{\mathrm{t}}$ to $400 \mathrm{MW}_{\mathrm{t}}$ range. There are several other processes that have been evaluated by the NGNP Project on a generic basis, (e.g., in comparison with conventional processes). The energy requirements for integration of the HTGR energy source with these processes are summarized in the following.

- Supply of heat to the primary reformer and electricity for ammonia and ammonia derivative production

The NGNP Project evaluated the use of the HTGR as an energy supply for ammonia and ammonia derivatives production. [TEV-666] Temperatures in the range $\geq 350^{\circ} \mathrm{C}$ to $700^{\circ} \mathrm{C}$ for natural gas preheating and replacing natural gas in the primary reformer have been evaluated. Higher temperatures could be applied in the primary reformer to improve efficiency. Higher ROT could eliminate the reforming stage which utilizes fuel gas combustion. A further reduction in the natural gas feed requirement could be achieved by developing a modification that separates the purge gas from the ammonia synthesis loop. The benefit of these changes has not been quantified at the time of this writing.

The evaluations performed by the NGNP Project investigated the energy requirements for a plant with the following capacities:
Ammonia
3,360 tons/day
Nitric acid
5,190 tons/day
Urea
2.940 tons/day
Ammonium Nitrate
3780 tons/day 


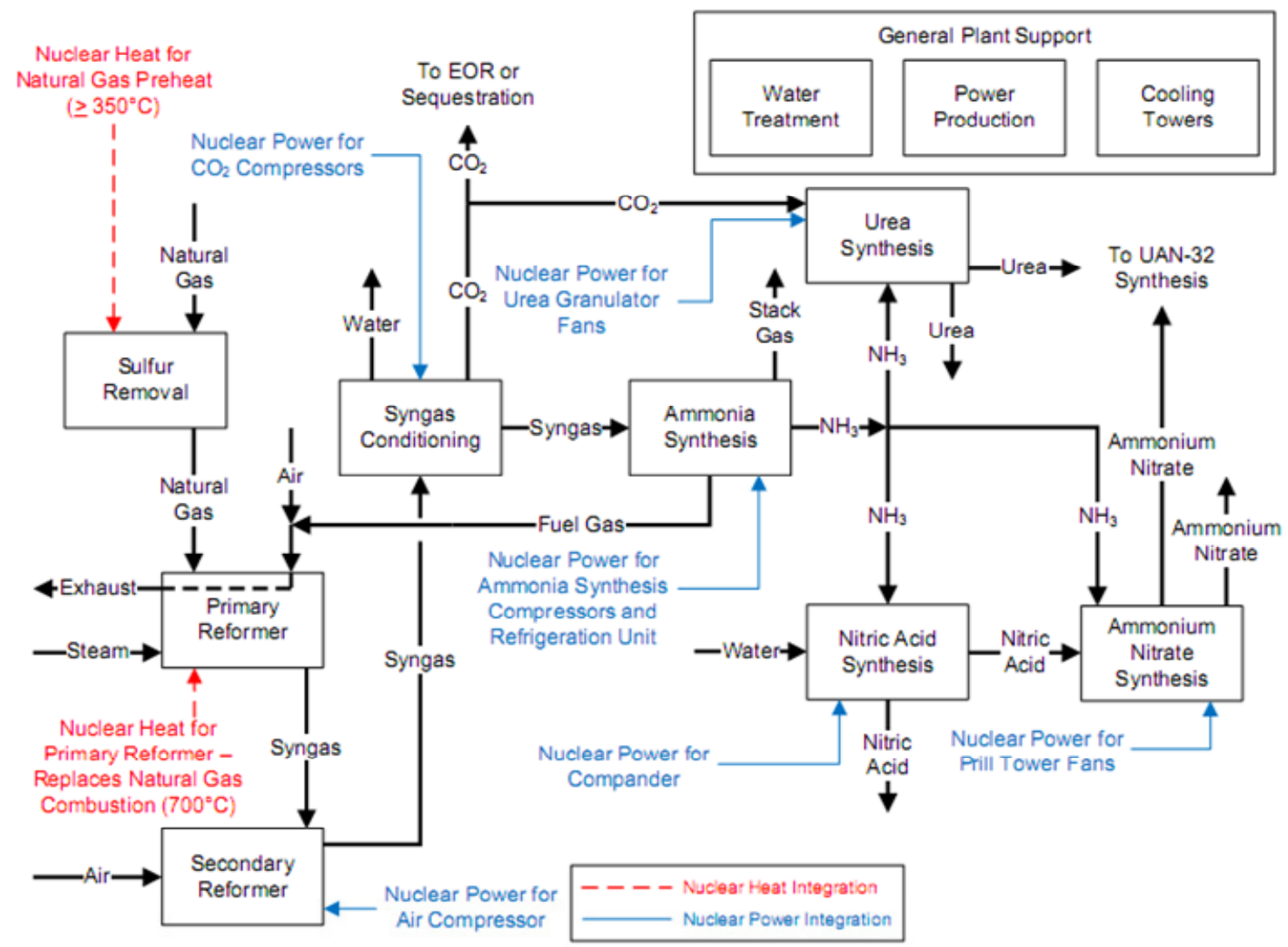

Figure A-2. Ammonia and ammonia derivatives production.

The energy requirements for the plant shown in Figure A-2 include $106 \mathrm{MW}_{\mathrm{e}}$ electricity and 190 $\mathrm{MW}_{\mathrm{t}}$ of process heat.

The NGNP Project also evaluated ammonia production using high temperature steam electrolysis (HTSE) supported by the HTGR plant to provide high purity hydrogen directly to the ammonia synthesizer along with nitrogen from combustion or from an air separation unit. The production rates were the same as listed above except that the HTSE plant also produces oxygen at a rate of $\sim 2,500$ tons day. The energy requirements for those applications include $770 \mathrm{MW}_{\mathrm{e}}$ to $879 \mathrm{MW}_{\mathrm{e}}$ electrical power and $222 \mathrm{MW}_{\mathrm{t}}$ to $262 \mathrm{MW}_{\mathrm{t}}$ process heat.

- Supply of process heat for coal or natural gas to gasoline using the methanol to gasoline process.

The NGNP Project assessed the integration of the HTGR with processes for converting coal and natural gas to gasoline using the methanol to gasoline (MTG) process. [TEV-667] Figure A-3 shows this integration using the HTSE hydrogen production process and coal as the feedstock. This process converts $\sim 98 \%$ of the carbon in the coal to $\sim 58,000 \mathrm{bpd}$ of gasoline and $\sim 9,100 \mathrm{bpd}$ of Liquified Petroleum Gas. This compares with a conversion rate of $\sim 45 \%$ for a conventional coal to MTG process. The energy requirements of the HTGR are $\sim 2,500 \mathrm{MW}_{\mathrm{e}}$ electrical power, primarily to the HTSE plant and $706 \mathrm{MW}_{\mathrm{t}}$ of process heat at up to $850^{\circ} \mathrm{C}$ to the HTSE plant. 


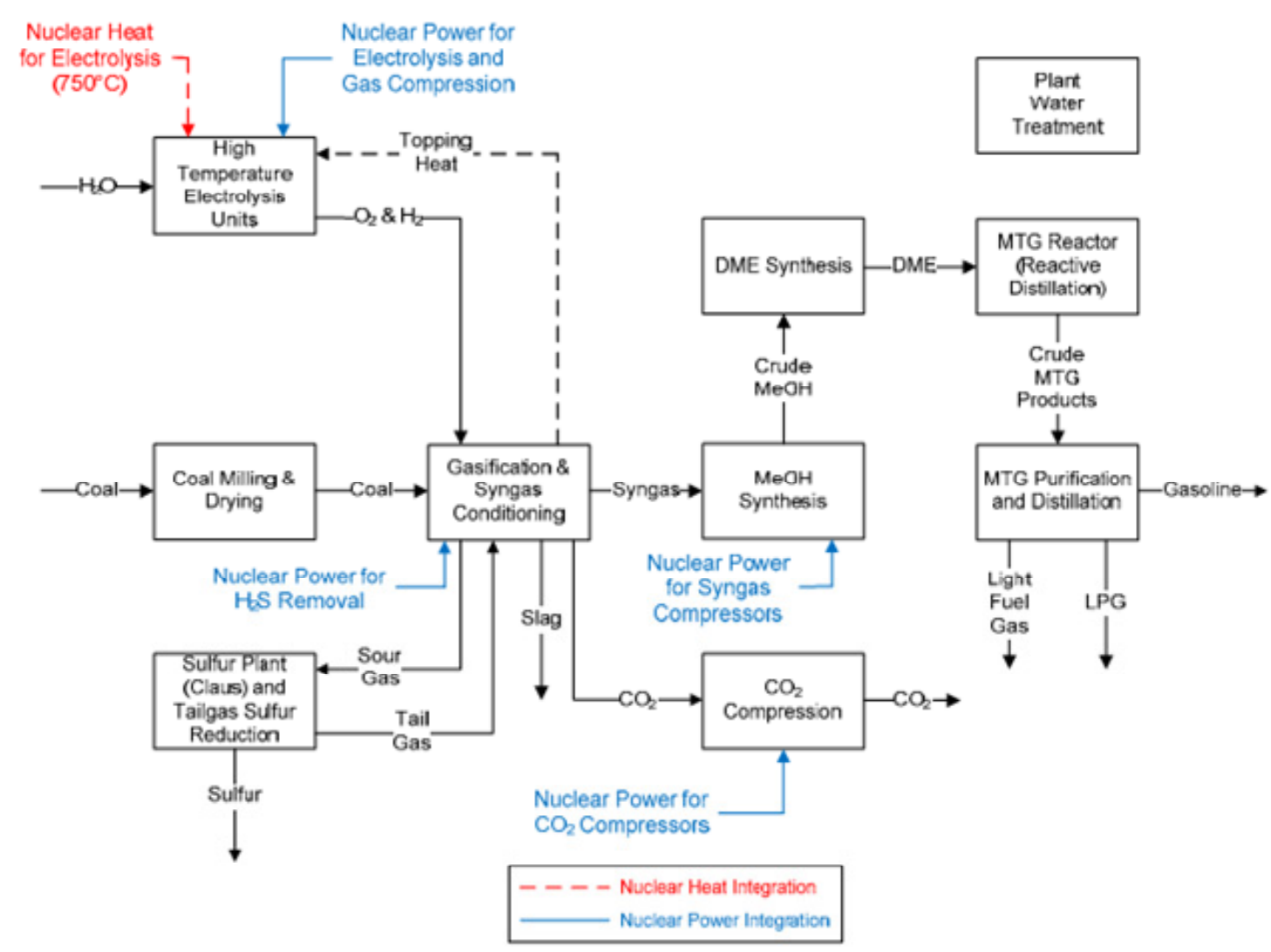

Figure A-3. Coal to Gasoline Conversion using the MTG Process.

The natural gas to gasoline plant size is smaller; 33,000 bpd of gasoline. For this assessment the HTGR plant was assumed to supply process heat to the primary reformer at $700^{\circ} \mathrm{C}$. Supply of process heat to the reformer at higher temperature, (e.g., up to $900^{\circ} \mathrm{C}$ ) would improve process efficiency.

- Supply of process heat for coal or natural gas to diesel

The NGNP Project evaluated the use of the HTGR to support conversion of coal and natural gas to diesel fuel in comparison with conventional processes. [TEV-672] Figure A-4 shows the integration of the HTGR with the high temperature steam electrolysis process for the conversion of coal to diesel, naphtha and liquefied petroleum gas (LPG). This process results in $\sim 95 \%$ carbon conversion to fuel versus the $\sim 35 \%$ conversion of a conventional process.

The process evaluated produced:

$$
\begin{array}{ll}
\text { Diesel } & 35,000 \mathrm{bpd} \\
\text { Naphtha } & 12,000 \mathrm{bpd} \\
\text { LPG } & 3,000 \mathrm{bpd}
\end{array}
$$

The energy requirements for this process include $2,324 \mathrm{MW}_{\mathrm{e}}$ of electricity and $762 \mathrm{MW}_{\mathrm{t}}$ of process heat at up to $850^{\circ} \mathrm{C}$. All of this energy supplies the HTSE plant.

The NGNP Project evaluation included a gas to liquids plant with the same output as that for the HTSE supported plant. This plant uses HTGR process heat for preheat of the combined natual gas feed and light gas recycle stream for hydrotreating, sulfur removal, pre-forming, and autothermal reforming. In addition, HTGR process heat is utilized to provide heat to the reboilers in the product upgrading and refining area. $588 \mathrm{MW}_{\mathrm{t}}$ of process heat is supplied by the HTGR for these processes. 


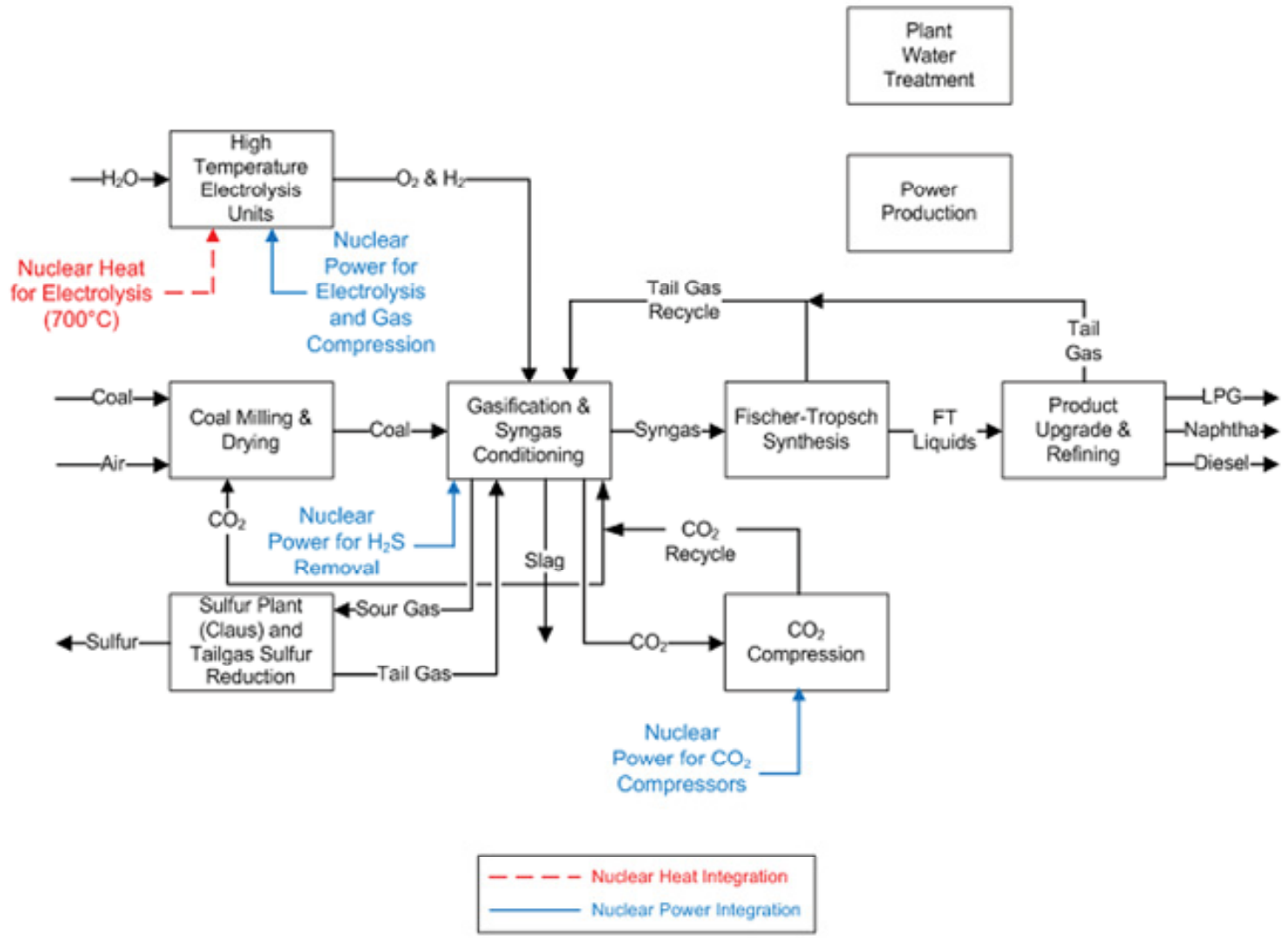

Figure A-4. Coal to Diesel Process.

- Hydrogen production

As noted in the preceding discussion many of the processes evaluated by the NGNP Project require hydrogen. In addition the Project identified merchant hydrogen supply as a potential market for HTGR technology. Accordingly, the NGNP Project has evaluated the application of the HTGR technology in support of two hydrogen production processes; the traditional steam methane reforming process and the high temperature steam electrolysis process.

- Hydrogen production using the HTGR as a heat source in the steam methane reforming process

The NGNP Project investigated the effect of varying ROT on the effectiveness of applying the HTGR process heat to the steam methane reforming process as shown in Figure A-5. [TEV 962] The HTGR is used as a substitute for natural gas firing in the steam reformer. Depending on the gas temperature from the HTGR it can supply a fraction or all of the heat required in the reformer. Below an ROT of $925^{\circ} \mathrm{C}$ some natural gas is burned to augment the HTGR process heat. Above $925^{\circ} \mathrm{C}$ ROT the process heat from the HTGR is sufficient. 


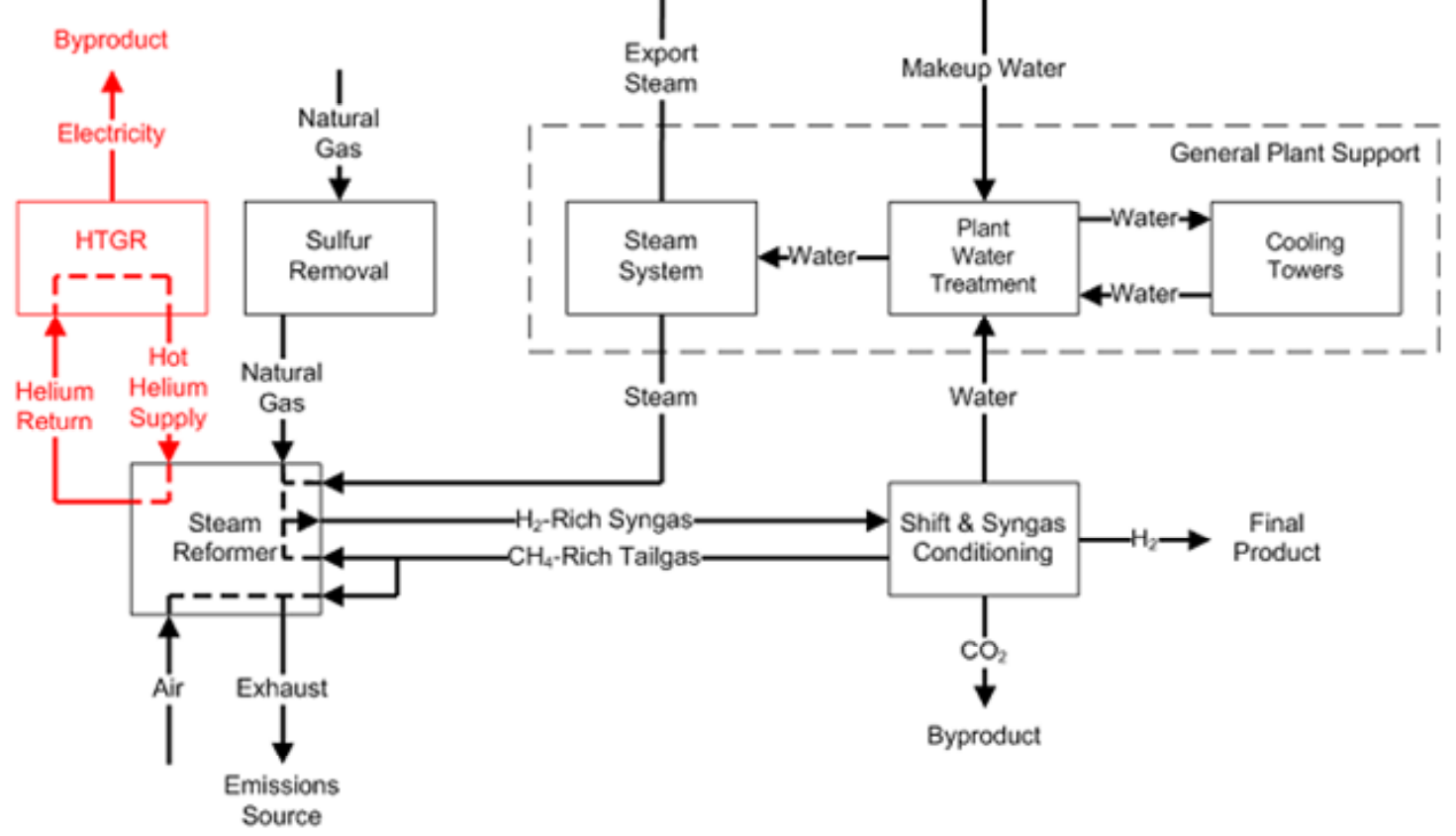

Figure A-5. Use of the HTGR as an energy source in the Steam Methane Reforming Process.

Figure A-6 shows the effect of ROT on the performance of the hydrogen process. An optimal ROT of around $875^{\circ} \mathrm{C}$ was identified for the reforming scenario analyzed. Note that this process generates significant amounts of steam that can be used in other parts of the facility, (e.g., for running steam turbines driving large compressors).

This analysis investigated the effect of ROTs in the range $725^{\circ} \mathrm{C}$ to $950{ }^{\circ} \mathrm{C}$ on the process performance. The analysis assumed a single hydrogen production train producing $130 \mathrm{MMSCFD}$ of hydrogen and between 176 to $54 \mathrm{MMBtu} /$ hour of steam. The amount of steam produced reduces as the ROT increases toward $875^{\circ} \mathrm{C}$ because of the lower amounts of natural gas burned in the process. Depending on the ROT between $117 \mathrm{MW}_{\mathrm{t}}$ to $177 \mathrm{MW}_{\mathrm{t}}$ of process heat and 14 $\mathrm{MW}_{\mathrm{e}}$ to $17 \mathrm{MW}_{\mathrm{e}}$ of electricity are required from the HTGR plant. This would require a HTGR nuclear heat supply rating of about $250 \mathrm{MW}_{\mathrm{t}}$. A multiple train system or integrating this energy demand in with other energy demands improves the economics of this application. 


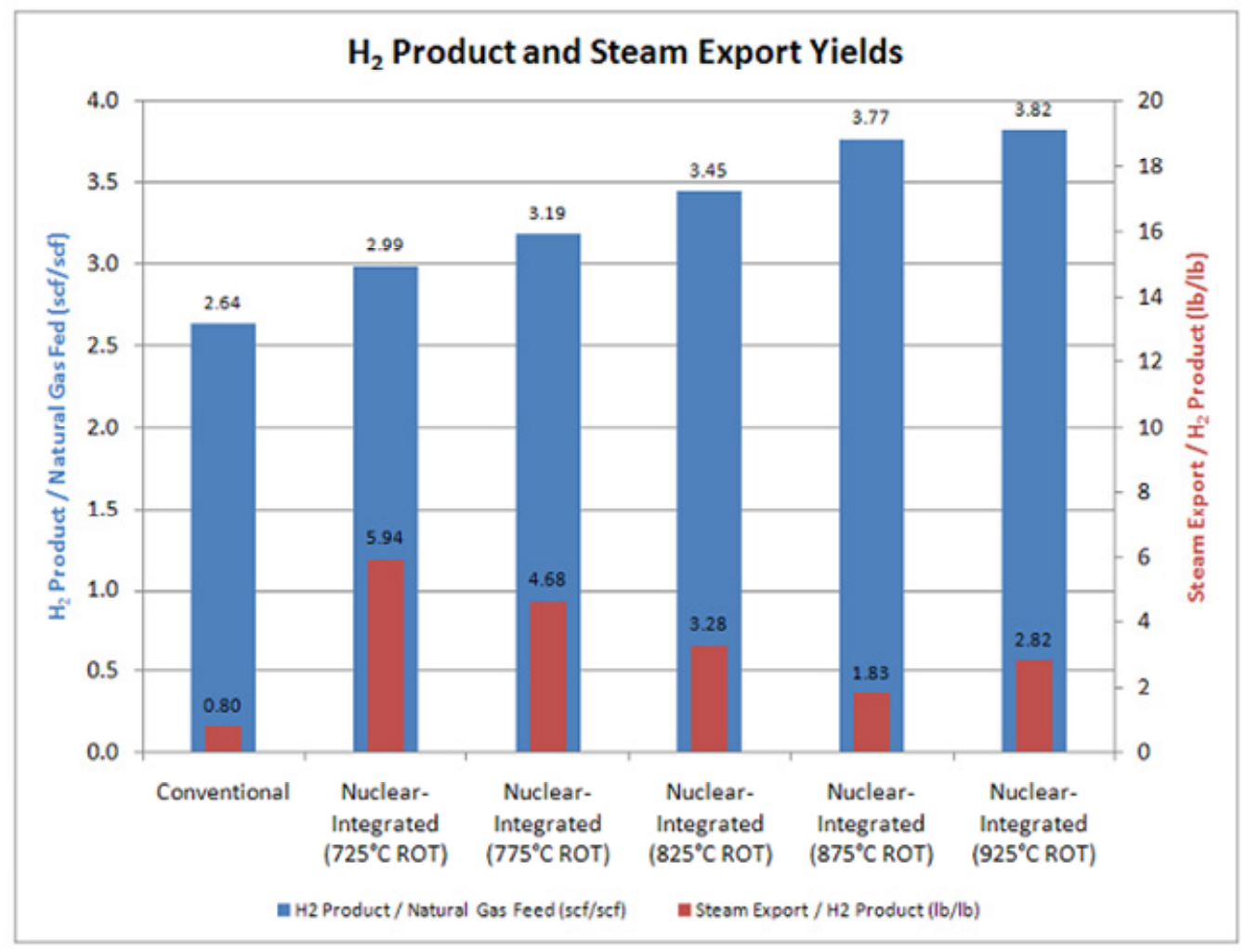

Figure A-6. HTGR Integrated Steam Methane Reforming Process Performance versus ROT.

- Hydrogen Production using high temperature steam electrolysis

The NGNP Project is tasked with development of the high temperature steam electrolysis (HTSE) hydrogen production system. The majority of the energy needs of the HTSE system is electricity; however, high temperature heat is required for steam generation in the electrolyzers. The efficiency and, therefore, the throughput of the process as a function of energy input is a strong function of the ROT. This is illustrated in Figure A-7 that shows that the efficiency of the process as a function of ROT. [TEV-981] As shown the higher the ROT the higher the efficiency. The study supporting this chart applied a $600 \mathrm{MW}_{\mathrm{t}}$ HTGR supplying process heat and electricity. For ROTs less than $800^{\circ} \mathrm{C}$ natural gas supplemental firing was used to optimize the performance of the electrolyzers. That explains the shift in the curve of Figure A-7 above an ROT of $800^{\circ} \mathrm{C}$. Production rates for the plant varied from $1.9 \mathrm{~kg} / \mathrm{sec}$ to $2.12 \mathrm{~kg} / \mathrm{sec}$ depending on the ROT and whether a steam or air sweep was employed. The detailed results of these analyses are summarized in Table A-2. 


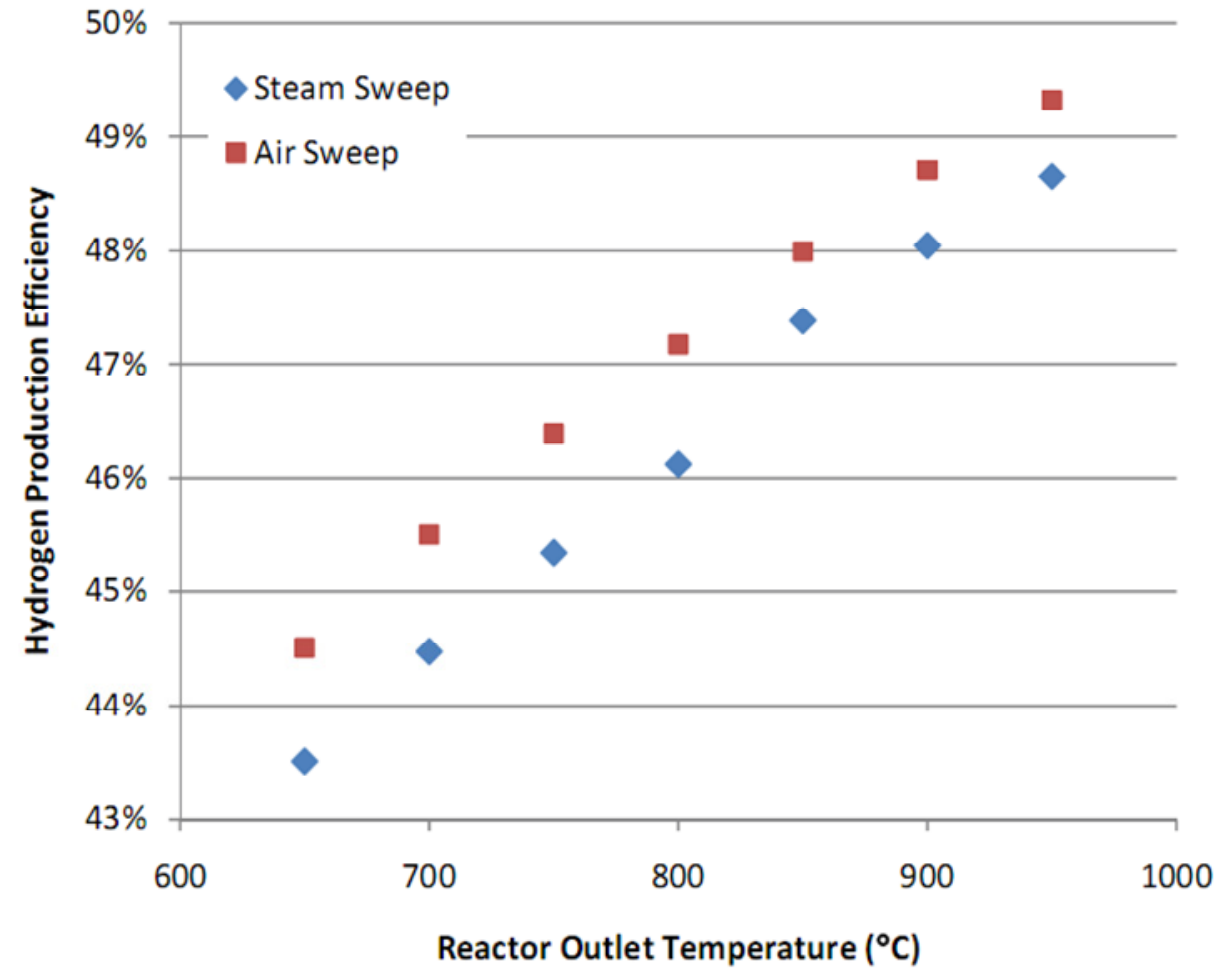

Figure A-7. HTSE Efficiency as a function of ROT.

A compilation of the characteristics of the energy required to support these processes and supply these products is summarized in Table A-2. 
Table A-2. Summary of identified end user needs.

\begin{tabular}{|c|c|c|c|c|c|c|c|}
\hline Process & $\begin{array}{c}\text { Reactor } \\
\text { Outlet } \\
\text { Temperature } \\
\end{array}$ & $\begin{array}{l}\text { Plant } \\
\text { Rating }\end{array}$ & Steam Conditions & $\begin{array}{c}\text { Electricity } \\
\text { Requirements }\end{array}$ & $\begin{array}{c}\text { High } \\
\text { Temperature } \\
\text { Fluid Conditions }\end{array}$ & Production & Comment \\
\hline Cogeneration & 750 to $950^{\circ} \mathrm{C}$ & $\begin{array}{l}600 \text { to } \\
2400 \mathrm{MWth}\end{array}$ & $\begin{array}{l}3500 \text { to } 4500 \text { psig, } \\
565 \text { to } 630^{\circ} \mathrm{C} \\
2500 \text { to } 30 \text { psig, } \\
540^{\circ} \mathrm{C} \text { to saturation }\end{array}$ & 240 to $500 \mathrm{MWe}$ & $\begin{array}{l}800 \text { to } 900^{\circ} \mathrm{C} \\
200 \text { to } 400 \mathrm{MWth}\end{array}$ & $\begin{array}{l}\text { Steam, Electricity } \\
\text { and High } \\
\text { Temperature } \\
\text { Fluids over wide } \\
\text { ranges }\end{array}$ & $\begin{array}{l}\text { The range of requirements } \\
\text { varies considerably } \\
\text { depending on the size of the } \\
\text { facility and the processes } \\
\text { involved. }\end{array}$ \\
\hline $\begin{array}{l}\text { Recovery of } \\
\text { bitumen from oil } \\
\text { sands }\end{array}$ & $750^{\circ} \mathrm{C}$ & 600 MWth & $\begin{array}{l}2500 \text { psig, } 540^{\circ} \mathrm{C} \\
\text { at the HTGR } \\
\text { Secondary system, } \\
1500 \text { psig, } 310^{\circ} \mathrm{C} \\
\text { at the well heads }\end{array}$ & $\begin{array}{l}\text { Not evaluated to- } \\
\text { date. Electricity } \\
\text { could be } \\
\text { generated in the } \\
\text { HTGR plant to } \\
\text { support oil sands } \\
\text { operations. }\end{array}$ & $\begin{array}{l}\text { Not evaluated to- } \\
\text { date } \\
\text { Process heat } \\
\text { would be used in } \\
\text { conjunction with } \\
\text { electricity to } \\
\text { produce hydrogen } \\
\text { for upgrading the } \\
\text { bitumen for } \\
\text { transfer to the } \\
\text { refinery }\end{array}$ & $\begin{array}{l}56,000 \text { barrels per } \\
\text { day of bitumen }\end{array}$ & $\begin{array}{l}\text { This plant would be } \\
\text { sufficient to provide required } \\
\text { energy to a 3-pad facility } \\
\text { with } 12 \text { well pairs per pad } \\
\text { with a nominal } 5 \mathrm{~km} \text { distance } \\
\text { from the centralized steam } \\
\text { supply to the wells. Multiple } \\
\text { units could be provided to } \\
\text { supply the energy to support } \\
\text { more wells, supply electricity } \\
\text { and supply hydrogen to a } \\
\text { major upgrading facility. }\end{array}$ \\
\hline $\begin{array}{l}\text { Electricity } \\
\text { Production }\end{array}$ & 750 to $950^{\circ} \mathrm{C}$ & Variable & Variable & $\begin{array}{l}\text { Power conversion } \\
\text { efficiencies vary } \\
\text { from } 40 \text { to } 49 \% \\
\text { depending on the } \\
\text { technology }\end{array}$ & $\begin{array}{l}750^{\circ} \mathrm{C} \text { to support } \\
\text { Rankine Cycle } \\
900 \text { to } 950^{\circ} \mathrm{C} \text { to } \\
\text { support Brayton } \\
\text { Cycle } \\
\text { [TBD] to support } \\
\text { supercritical } \mathrm{CO}_{2} \\
\text { cycle }\end{array}$ & Variable & $\begin{array}{l}\text { PCS technologies being } \\
\text { investigated include Rankine } \\
\text { and supercritical steam } \\
\text { turbine generators, direct } \\
\text { Brayton cycle, indirect } \\
\text { Brayton combined cycle, } \\
\text { supercritical } \mathrm{CO}_{2} .\end{array}$ \\
\hline $\begin{array}{l}\text { Ammonia and } \\
\text { derivatives using } \\
\text { HTGR process } \\
\text { heat in primary } \\
\text { reformer }\end{array}$ & $\begin{array}{l}750^{\circ} \mathrm{C} \text { as a } \\
\text { minimum }\end{array}$ & 450 MWth & N/A & $106 \mathrm{MWe}$ & $\begin{array}{l}>350 \text { to } 700^{\circ} \mathrm{C} \\
190 \mathrm{MWth}\end{array}$ & $\begin{array}{l}\text { Ammonia } \\
3,360 \text { tpd } \\
\text { Nitric Acid - } \\
5,190 \text { tpd } \\
\text { Urea }-2,940 \text { tpd } \\
\text { Ammonium } \\
\text { Nitrate - } \\
\text { 3,780 tpd }\end{array}$ & $\begin{array}{l}\text { Process efficiency can be } \\
\text { improved with a higher ROT }\end{array}$ \\
\hline
\end{tabular}




\begin{tabular}{|c|c|c|c|c|c|c|c|}
\hline Process & $\begin{array}{c}\text { Reactor } \\
\text { Outlet } \\
\text { Temperature }\end{array}$ & $\begin{array}{l}\text { Plant } \\
\text { Rating }\end{array}$ & Steam Conditions & $\begin{array}{c}\text { Electricity } \\
\text { Requirements }\end{array}$ & $\begin{array}{c}\text { High } \\
\text { Temperature } \\
\text { Fluid Conditions }\end{array}$ & Production & Comment \\
\hline $\begin{array}{l}\text { Ammonia and } \\
\text { derivatives using } \\
\text { HTSE }\end{array}$ & 750 to $900^{\circ} \mathrm{C}$ & 2,500 MWth & N/A & 770 to $880 \mathrm{MWe}$ & 700 to $875^{\circ} \mathrm{C}$ & $\begin{array}{l}\text { Same as preceding } \\
\text { with } \sim 2,500 \text { tpd of } \\
\text { oxygen added }\end{array}$ & $\begin{array}{l}\text { The higher ROT is required } \\
\text { to provide the best process } \\
\text { efficiency }\end{array}$ \\
\hline $\begin{array}{l}\text { Coal to Gasoline } \\
\text { Conversion using } \\
\text { the MTG process }\end{array}$ & 750 to $950^{\circ} \mathrm{C}$ & 6,900 MWth & $\mathrm{N} / \mathrm{A}$ & $2,500 \mathrm{MWe}$ & $\begin{array}{l}700 \text { to } 900^{\circ} \mathrm{C} \\
706 \text { MWth }\end{array}$ & \begin{tabular}{|l|} 
Gasoline - \\
$58,000 \mathrm{BPD}$ \\
$\mathrm{LPG}-9,100 \mathrm{BPD}$
\end{tabular} & $\begin{array}{l}\text { The higher ROT temperature } \\
\text { improves the overall } \\
\text { efficiency of the process }\end{array}$ \\
\hline $\begin{array}{l}\text { Natural Gas to } \\
\text { Gasoline using } \\
\text { the MTG Process }\end{array}$ & $\begin{array}{l}750^{\circ} \mathrm{C} \\
\text { minimum }\end{array}$ & 720 MWth & N/A & $115 \mathrm{MWe}$ & $\begin{array}{l}700^{\circ} \mathrm{C} \\
387 \mathrm{MWth}\end{array}$ & $\begin{array}{l}\text { Gasoline - } \\
\text { 33,500 BPD } \\
\text { 5,300 BPD LPG }\end{array}$ & $\begin{array}{l}\text { Higher ROT would improve } \\
\text { the reforming efficiency }\end{array}$ \\
\hline $\begin{array}{l}\text { Coal to Synthetic } \\
\text { Diesel } \\
\text { Conversion }\end{array}$ & 750 to $950^{\circ} \mathrm{C}$ & 6,571 MWth & N/A & 2,324 MWe & $\begin{array}{l}700 \text { to } 900^{\circ} \mathrm{C} \\
762 \mathrm{MWth}\end{array}$ & \begin{tabular}{l|} 
Diesel -- \\
35,000 BPD \\
Naphtha - \\
12,000 BPD \\
LPG $-3,000$ BPD \\
\end{tabular} & $\begin{array}{l}\text { To be economic compared } \\
\text { with conventional crude } \\
\text { refining and coal to liquid } \\
\text { processes the ROT needs to } \\
\text { be as high as achievable. }\end{array}$ \\
\hline $\begin{array}{l}\text { Natural gas to } \\
\text { diesel conversion }\end{array}$ & $750^{\circ} \mathrm{C}$ & 600 MWth & N/A & $\mathrm{N} / \mathrm{A}$ & $\begin{array}{l}750^{\circ} \mathrm{C} \\
588 \mathrm{MWth}\end{array}$ & Same as preceding & $\begin{array}{l}\text { In this case a higher ROT } \\
\text { does not improve the process } \\
\text { results. Autothermal } \\
\text { reforming is used, instead of } \\
\text { traditional steam methane } \\
\text { reforming. Therefore, the } \\
\text { HTGR heat is only used for } \\
\text { preheat. }\end{array}$ \\
\hline $\begin{array}{l}\text { Hydrogen using } \\
\text { HTGR process } \\
\text { heat in Steam } \\
\text { Methane } \\
\text { Reformer }\end{array}$ & 725 to $925^{\circ} \mathrm{C}$ & 250 MWth & N/A & $\begin{array}{l}14 \text { MWe to } 17 \\
\text { MWe }\end{array}$ & $700^{\circ} \mathrm{C}$ to $900^{\circ} \mathrm{C}$ & $\begin{array}{l}\text { Hydrogen - } \\
130 \text { MMSCFD } \\
\text { Steam - } \\
176 \text { to } 54 \\
\text { MMBtu/hour }\end{array}$ & $\begin{array}{l}\text { The throughput and } \\
\text { economic viability of this } \\
\text { application peak at an ROT } \\
\text { of } \sim 875^{\circ} \mathrm{C} \text {. } \\
\text { Multiple production trains } \\
\text { improve economics. } \\
\text { Steam production reduces as } \\
\text { the ROT is increased. }\end{array}$ \\
\hline Hydrogen & $650^{\circ} \mathrm{C}$ & $600 \mathrm{MWth}$ & N/A & $239 \mathrm{MWe}$ & $\begin{array}{l}625 \mathrm{C} @ 7 \mathrm{MPa}, \\
54 \mathrm{MWth}\end{array}$ & $1.94 \mathrm{~kg} / \mathrm{s}$ & $\begin{array}{l}\text { The efficiency of the process } \\
\text { increases with increasing }\end{array}$ \\
\hline
\end{tabular}




\begin{tabular}{|c|c|c|c|c|c|c|c|}
\hline Process & $\begin{array}{c}\begin{array}{c}\text { Reactor } \\
\text { Outlet } \\
\text { Temperature }\end{array} \\
\end{array}$ & $\begin{array}{c}\text { Plant } \\
\text { Rating }\end{array}$ & Steam Conditions & $\begin{array}{c}\text { Electricity } \\
\text { Requirements }\end{array}$ & \begin{tabular}{|c|c} 
High \\
Temperature \\
Fluid Conditions
\end{tabular} & Production & Comment \\
\hline \multirow[t]{6}{*}{ Using HTSE } & $700^{\circ} \mathrm{C}$ & $600 \mathrm{MWth}$ & $\mathrm{N} / \mathrm{A}$ & $244 \mathrm{MWe}$ & $\begin{array}{l}\text { 675 C@ } @ 7 \mathrm{MPa}, \\
56 \mathrm{MWth} \\
\end{array}$ & $1.98 \mathrm{~kg} / \mathrm{s}$ & \multirow[t]{6}{*}{ ROT. } \\
\hline & $750^{\circ} \mathrm{C}$ & $600 \mathrm{MWth}$ & N/A & $248 \mathrm{MWe}$ & $\begin{array}{l}725 \mathrm{C} @ 7 \mathrm{MPa}, \\
58 \mathrm{MWth} \\
\end{array}$ & $2.02 \mathrm{~kg} / \mathrm{s}$ & \\
\hline & $800^{\circ} \mathrm{C}$ & 600 MWth & N/A & $252 \mathrm{MWe}$ & $\begin{array}{l}775 \mathrm{C} @ 7 \mathrm{MPa}, \\
59 \text { MWth } \\
\end{array}$ & $2.05 \mathrm{~kg} / \mathrm{s}$ & \\
\hline & $850^{\circ} \mathrm{C}$ & $600 \mathrm{MWth}$ & N/A & $255 \mathrm{MWe}$ & $\begin{array}{l}825 \mathrm{C} @ 7 \mathrm{MPa}, \\
62 \mathrm{MWth} \\
\end{array}$ & $2.07 \mathrm{~kg} / \mathrm{s}$ & \\
\hline & $900^{\circ} \mathrm{C}$ & 600 MWth & N/A & $258 \mathrm{MWe}$ & $\begin{array}{l}875 \mathrm{C} @ 7 \mathrm{MPa}, \\
64 \mathrm{MWth} \\
\end{array}$ & $2.10 \mathrm{~kg} / \mathrm{s}$ & \\
\hline & $950^{\circ} \mathrm{C}$ & 600 MWth & N/A & $261 \mathrm{MWe}$ & $\begin{array}{l}925 \mathrm{C} @ 7 \mathrm{MPa}, \\
65 \mathrm{MWth}\end{array}$ & $2.12 \mathrm{~kg} / \mathrm{s}$ & \\
\hline
\end{tabular}




\section{A-5. References}

INL 2009 INL/LTD-09-17394, Evaluating Use of HTGR Technology as an Energy Supply for Petrochemical Facilities, September 24, 2009

TEV-666 Nuclear-Integrated Ammonia Production Analysis, Rev 2, 5/25/10

TEV-667 Nuclear-Integrated Methanol-to Gasoline Production Analysis, Rev 1, 5/15/10

TEV-672 Nuclear-Integrated Coal and Gas to Liquids Production Analysis, Rev 1, 5/15/10

TEV-674 Power Cycles for the Generation of Electricity from a Next Generation Nuclear Plant, Rev 1, $2 / 11 / 10$

TEV-704 Nuclear Assisted Oil Sands Recovery via Steam-Assisted Gravity Drainage, Rev 1, 2/22/10

TEV-962 Sensitivity of Hydrogen Production via Steam Methane Reforming (SMR) to High

Temperature Gas Reactor (HTGR) Reactor Outlet Temperature (ROT) Economic Analysis, 8/31/10

TEV-981 An Analysis of the Effect of Reactor Outlet Temperature of a High Temperature Reactor on Electric Power Generation, Hydrogen Production, and Process Heat, Draft, 8/31/10 